\title{
オゾン添加活性污泥法による 有機性微量污染物質含有廃水の処理特性
}

\author{
西村 文武 ${ }^{1 *}$ ・岡田 由希子 ${ }^{2}$ ・増田 理子 $^{3}$ - 中川 佑子 ${ }^{1}$ • \\ 日高 平 $^{4} \cdot$ 藤原 拓 $^{5} \cdot$ 津野 洋 ${ }^{1,6}$ \\ ${ }^{1}$ 京都大学大学院 工学研究科都市環境工学専攻（† 615-8540 京都市西京区京都大学桂C1） \\ 2株式会社 四電技術コンサルタント 河川部（テ761-0121 香川県高松市牟礼町牟礼1007-3） \\ 3名古屋工業大学大学院 工学研究科社会工学専攻（广466-8555 名古屋市昭和区御器所町） \\ 4(独)土木研究所材料資源研究グループ（テ305-8516 茨城県つくば市南原1番地6) \\ 5 高知大学教育研究部自然科学系農学部門（干783-8502 高知県南国市物部乙200） \\ 6 大阪産業大学人間環境学部生活環境学科（广574-8530 大阪府大東市中垣内3-1-1） \\ * E-mail: nishimura.fumitake.3n@kyoto-u.ac.jp
}

\begin{abstract}
オゾン添加活性污泥法では, 污泥の性状改善とともに污泥発生量削減が特に注目されているが，一方で オゾンの酸化力により污泥の液化と同時に, 実下廃水中に含有される難分解性物質(EDCs)や生物活性を阻 害寸る物質(フェノール)の酸化分解も期待される。オゾン添加により, これまで注目されてきた余剩污泥 減容効果, 沈降性改善効果に加え, 処理水質の向上と生物活性阻害の低減効果も図孔ると考え, その可能 性について実験により調查すると共に, オゾン添加時の污泥減容と阻害性物質除去の比率等の反応動力学 について検討した。オゾン添加活性污泥法は, 生物活性阻害性物質除去と生物活性(硝化活性)維持の観点 からも, 従来法よりも優れていることが分かった。 発生污泥量削減の観点から開発されたオゾン添加活性 污泥法であるが，処理の安定性向上及び微量污染物質除去の観点からも利点があることを明らかにした。
\end{abstract}

Key Words : ozone, activated sludge, decomposition of phenol, EDCs, ozone-added activated sludge process

\section{1. はじめに}

下廃水中にはさまざまな有機化学物質が存在し, 中に は比較的低い濃度でも浄化に関する微生物の活性に影響 を与えるものや，放流水中に存在すれば放流先での水域 生態系に影響を与えうるものがある.フェノールもその ような特性を持つ化合物の一つであり，それを分子骨格 にもつフェノール類は，消毒剤や防腐剂として広く使用 されていること, また農薬, 医薬品, 染料等の原料とし ても用いられることから，しばしば下水中に検出されて いる. フェノールは数 50mg/L程度の濃度でも微生物の 活性阻害もたらすことや急激な負荷を与えるとフロック 形成を阻害寸る可能性があることから ${ }^{1)}$ ， その適切な制 御は, 生物学的廃水処理プロセスにおいて重要な事項と なる. また内分泌かく乱作用のある化合物(EDCs)も下水 中に存在することが知られており，その適切な除去が希 求されている. 好気的条件下で生物学的作用により除去 されることがわかっているが，酸素が枯渇すると再度液
中濃度が上昇する現象も報告されており2)，確実な除去 法の適用が求められている. フェノール類の処理にはこ れまでオゾンの適用が，比較的簡便でかつ有効な手法と して注目されてきてきだ3. EDCsについてもオン゙ンとの 反応性はよく，簡易でから確実に除去しうる方法として， オゾン処理の適用が試みられている ${ }^{45)}$. 一方, 近年標準 活性污泥法にオゾンを付加するオゾン添加活性污泥法が, 污泥の減容化 ${ }^{6778)}$ やバルキング対策9)として研究され，一 部では実施設への適用についても検討されている のプロセスの原理はオゾンの酸化力を用いた污泥の液化 とその後の生物代謝による無機化の促進であるが，廃水 中に生物活性阻害作用のある有機化学物質が混入してい る場合では，その酸化-除去作用にもオン゙ンが寄与する ものと考えられる.ここでは, 生物活性阻害性を有する 化学物質としてフェノールを取り上げる. また下水中に 存在し, 微量でも生態系への影響を与えうる化合物とし てEDCsを取り上げる.これらの都市下水中での濃度レ ベルは異なるが、オゾンとの反応性は高く有機性微量污 
染物質が液中で污泥と共存している時のオゾンの反応性 について検討する。フフノールは活性阻害のみならず沈 降性も悪化させうるが，オゾンは凝集性を向上させると の報告もあり ${ }^{11)}$ ，オゾン添加が生物活性阻害を抑制する とともに, 凝集効果を促進し, 結果として安定した処理 の実施も期待できると考えられる，そこで，本研究では， オゾン添加活性污泥法でのフェノールならびにEDCs含 有廃水処理一の適用を試みた。 まず，オゾン添加を行う ことで，これまで注目されてきた余剩污泥減容効果に加 え，有機性微量污染物質除去等の処理水質の向上と生物 活性阻害の低減効果も期待できると考え，污泥減容効果 と阻害性物質除去効果に対して, 添加したオゾンがどの ような割合で寄与しているのか等の反応性やその動力学 について回分実験により検討した．また，ラボスケール の反応器を用いた処理実験を実施し, 連続処理における 生物活性阻害の低減効果と凝集・沈降性への効果を定量 的に把握することとした．これらの実験を通じて，処理 安定性の観点からオゾン添加活性污泥法の処理特性を評 価することを試みた。
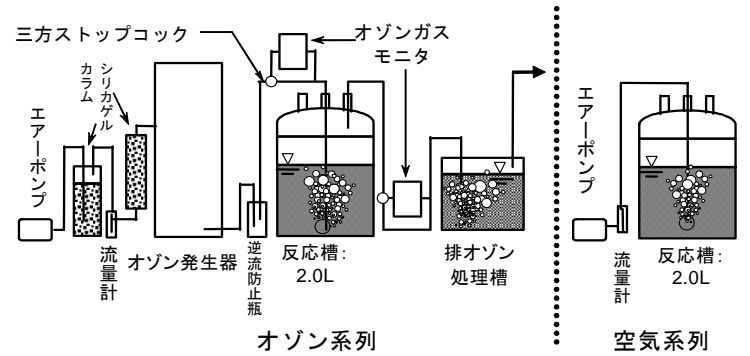

図-1 半回分実験装置概略図

表-1 半回分実験条件

\begin{tabular}{|ll|c|}
\hline フェノール濃度 & $(\mathrm{mg} / \mathrm{L})$ & 20 \\
\hline 採水量 & $(\mathrm{mL})$ & 50 \\
\hline オゾフ濃度 & $(\mathrm{mg} / \mathrm{L})$ & 5 \\
\hline ガス流量 & $(\mathrm{L} / \mathrm{min})$ & 0.3 \\
\hline 污泥量 & $(\mathrm{L})$ & 2 \\
\hline
\end{tabular}

表-2 半回分実験ケース

\begin{tabular}{|c|c|c|c|c|}
\hline $\begin{array}{l}\text { 実験 } \\
\text { ケース }\end{array}$ & $\begin{array}{l}\text { フェノール } \\
\text { 濃度 }(\mathrm{mg} / \mathrm{L})\end{array}$ & \begin{tabular}{|c} 
MLSS \\
(mgSS/L)
\end{tabular} & $\begin{array}{l}\text { 添加 } \\
\text { ガス }\end{array}$ & 備考 \\
\hline Case 1 & 20 & 0 & $\mathrm{O}_{3}$ & $\begin{array}{c}\text { オゾンによるフェノー } \\
\text { ル分解特性 }\end{array}$ \\
\hline Case 2 & 20 & 0 & Air & $\begin{array}{c}\text { 対照(フェノール揮散 } \\
\text { の確認) }\end{array}$ \\
\hline Case 3 & 20 & 2500 & $\mathrm{O}_{3}$ & 污泥混在の影響 \\
\hline Case 4 & 20 & 2500 & Air & $\begin{array}{c}\text { 対照(フェノールの污 } \\
\text { 泥への吸着) }\end{array}$ \\
\hline Case 5 & 0 & 2500 & $\mathrm{O}_{3}$ & 污泥液化の特性 \\
\hline Case 6 & 0 & 2500 & Air & $\begin{array}{c}\text { 対照(空気曝気でのSS } \\
\text { の減少の確認) }\end{array}$ \\
\hline Case 7 & 20 & 1250 & $\mathrm{O}_{3}$ & 污泥混在の影響 \\
\hline Case 8 & 20 & 625 & $\mathrm{O}_{3}$ & 污泥混在の影響 \\
\hline
\end{tabular}

\section{2. 実験方法}

(1) オゾンによる污泥液化とフェノールの分解機構把握 a) 半回分実験装置

回分実験装置の概略図を図-1に示す。オゾン発生装置 は日本オゾン株式会社製(O-2-3)を使用した．反応槽には セパラブルフラスコ(旭テクノグラス $\phi=100 \mathrm{~mm}$ $\mathrm{H}=247 \mathrm{~mm}$ 有効容積2.0L)を用い, 反応槽の上部にはガス 注入口と排出口を作製し，送排気用のテフロンチューブ を接続した. オゾン発生器と反応槽の間のチューブをテ フロン製三方ストップコックにより分岐させ片方に溶存 オゾンガスモニタ(萑原実業株式会社製 EG-600)を接続し, オゾン化空気の流れを注入オゾンガス濃度測定時に，測 定器に導入できるよう切り替えられるようにした. 反応 槽の後には, 排出オゾンを処理するために20g/Lのよう 化カリウム溶液を $3 \mathrm{~L}$ 入れた排オゾン処理槽を設置した 反応槽と排オゾン処理槽の間のチューブをテフロン製三 方ストップコックにより分岐させ片方にオゾンガスモニ 夕(萑原実業株式会社製 EG-600)を接続し，気体の流れを 切り替えることで，オゾンガス濃度を測定できるように した．標準活性污泥法で運転されているM市下水処理場 より採取してきた返送污泥を反応槽にそれぞれ2しずつ入 れ，実験に供した。同様の処理原理で，よりオゾン接触 効率を高めた内径 $10.0 \mathrm{~cm}$, 高さ $100 \mathrm{~cm}$, 有効容積 6 しの半 回分式反応器を用いてEDCs含有混合液の処理を行い, EDCsの処理特性についても検討した，用いた混合液は 都市下水を標淮活性污泥法やAO法で運転しているK市下 水処理場より採取した返送污泥を用いた.

\section{b) オゾン処理方法および条件}

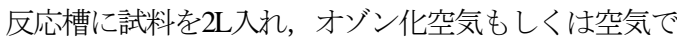
曝気する. そして $0,5,13,26,43,63$ 分に反応槽上部から50 $\mathrm{mL} ゙$ つ一定量採取した．その後GF/Bガラス繊維ろ紙(孔 径 $1 \mu \mathrm{m})$ にてろ過したろ液を採取し, 分析した. 分析項目 は，反応槽内混合液内での水温，pH，SS，DOC，無機 陽イオン，無機陰イオン，フェノールを測定するととも に, オゾンガス濃度を測定した. イオン類の測定にはイ オンクロマトグラフ(島津製作所LC-10A)を用いた。また, オゾンガス濃度は，オゾンガスモニタを使用した。 その 他の水質項目は下水試験方法 ${ }^{12} に$ に準拠した. 実験条件を 表-1に示す. 流入オゾンガス濃度は $5 \mathrm{mgO}_{3} / \mathrm{L}$ ，オゾン化 空気流量，空気流量はともに 0.3 L/minとした。また初期 フェノール濃度を20 mgLとした. 返送污泥はM市下水処 理場より採取した返送污泥を，水道水を用いて2回洗浄 した後に実験に供した．実験ケースを表-2に示寸．また

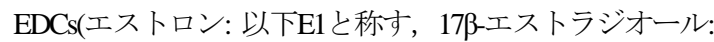
以下E2と称す, エストリオール: 以下E3と称す, エチニ ルエストラジオール: 以下EE2と称す，およびビスフェノ 
ールA: 以下BPAと称す)の処理については, 表-3に示す污 泥を用い，オゾン処理を行った．EDCsは，好気条件と 酸素枯渇条件で挙動が異なることが知られており2)，そ の影響についても検討することとした. Case 10では接触

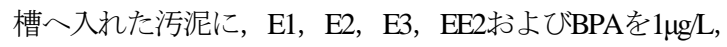

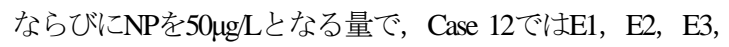

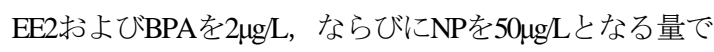
添加し，30分攪拌を行った後，オゾン処理を行った. 同 一条件で2回オゾン処理を行い，Case 9およびCase 10では 1回目は30分間, 2回目は300分間, Case 11およびCase 12で は1回目は20分間，2回目では420分間処理を行った．全 てのCase において，0分のサンプリングを行った後にオ ゾン接触槽内の試水量を $6.0 \mathrm{~L}$ してオゾン処理を開始し た. EDCsはガスクロマトグラフ質量分析計(GC/MS)によ る機器分析による測定を行った. 下水試験方法 ${ }^{13)}$ おび Waters社の提唱している手法 ${ }^{14)}$ に準拠し，坂本が検討し た測定方法に基づき行った ${ }^{15}$. 本研究で用いた標準試薬 として，E1，E2，E3，EE2およびE2-17acetateはSIGMAALDRICHジャパン, NPは関東化成工業, BPAは和光純 薬工業製のものを用いた.

\section{(2) オゾン添加活性污泥法による連続処理特性把握}

ラボスケールの連続処理実験装置の概要を図-2に示寸. 装置はオゾン反応槽 $(\varphi=90 \mathrm{~mm} \mathrm{H}=260 \mathrm{~mm}$ 有効容積1.0L), 生物反応槽(有効容積10L), 最終沈殿池(有効容積1.2L),

表-3 対象とした污泥の性質

\begin{tabular}{|c|c|c|c|c|c|}
\hline $\begin{array}{l}\text { 実験 } \\
\text { ケース }\end{array}$ & $\begin{array}{c}\text { 下水処理場 } \\
\text { におおる处理法 }\end{array}$ & $\begin{array}{c}\text { MLSS 濃度 } \\
\text { [mgSS/L] }\end{array}$ & $\begin{array}{c}\text { VSS/SS 比 } \\
{[-]}\end{array}$ & $\mathrm{pH}$ & $\begin{array}{l}\text { 温度 } \\
{\left[{ }^{\circ} \mathrm{C}\right]} \\
\end{array}$ \\
\hline Case 9 & \multirow{2}{*}{ 標淮活性污泥法 } & 4,910 & 0.78 & 6.80 & 26.8 \\
\hline Case 10 & & 3,870 & 0.83 & 6.76 & 23.8 \\
\hline Case 11 & \multirow{2}{*}{$\begin{array}{l}\text { 嫌気/好気 } \\
\text { 活性污泥法 }\end{array}$} & 9,490 & 0.84 & 6.61 & 18.0 \\
\hline Case 12 & & 10,000 & 0.86 & 6.66 & 18.6 \\
\hline
\end{tabular}

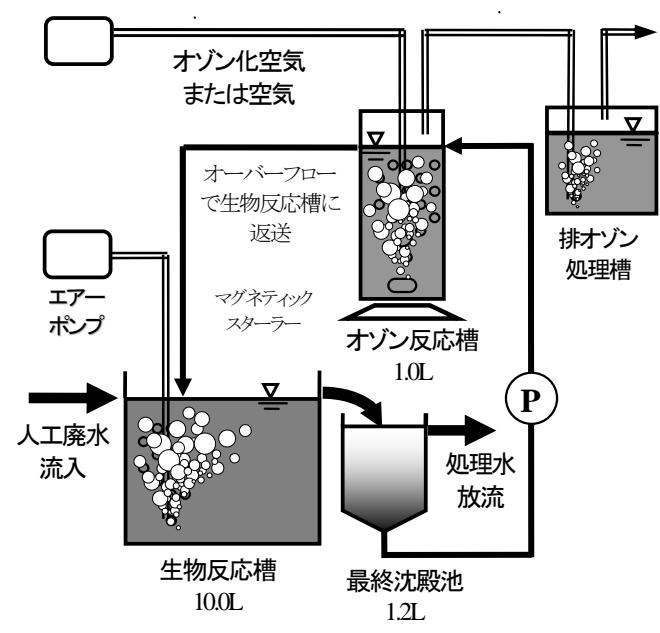

図-2 連続処理実験装置の概要
排オゾン処理槽からなる. 生物反応槽および反応槽は,

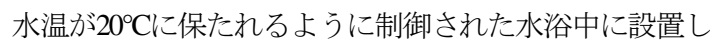
た. 反応槽内は, 污泥が常に攪拌され反応されやすくす るために，マグネッチスターラーで攪拌した．生物反応 槽においても槽内を完全混合状態にするために攪拌機を 用いた. 最終沈殿池では壁面に污泥が付着するのを防ぐ ために攪汼機を使用し，污泥が攪乱しない程度の操作を 行った. 反応槽からの排出ガスは排オゾン処理槽(20g/L のヨウ化カリウム水溶液 : 有効容積 $3.0 \mathrm{~L}$ )にて残存オゾン を除去し, 系外一排出させた. 各槽間はシリコンチュー ブで接続し，人工廃水はチューブポンプによって生物反 応槽に流入させた. 生物反応槽での混合液はオーバーフ ローによって最終沈殿池へ移行させ，固液分離後，液は 処理水として系外一排出した. 沈殿污泥は最終沈殿池底 部から污泥返送ポンプによって引き抜き，オゾン反応槽 に導入させた. オゾン反応槽でオゾンと反応後, オーバ ーフローによって生物反応槽に返送させた．実験装置に M市下水処理場より採取してきた返送污泥を初期MLSS 濃度が2,500 mg/になるように調製して, 生物反応槽に 8L投入して処理実験を開始した，装置は同様のものを2 器作製し，ひとつは反応槽にオゾン化空気を連続的に添

表-4 連続実験装置運転条件

\begin{tabular}{|c|c|c|}
\hline 項目 & オゾン系 & 空気系 \\
\hline オゾン反応槽へのガス流量(L/min) & 0.3 & 0.3 \\
\hline 人工発水流量 Q(L/hr) & 1.53 & 1.53 \\
\hline 返送污泥流量 Qr(L/hr) & 0.61 & 0.61 \\
\hline HRT(hr) & 6.56 & 6.56 \\
\hline 污泥返送率(\%) & 40.0 & 40.0 \\
\hline
\end{tabular}

表-5 各 Runのオゾン濃度とフェノール濃度

\begin{tabular}{|c|c|c|c|}
\hline & $\begin{array}{c}\text { 経過日数 } \\
(\text { 日) }\end{array}$ & $\begin{array}{c}\text { 添加オゾンガス } \\
\text { 濃度 }\left(\mathrm{mgO}_{3} / \mathrm{L}\right)\end{array}$ & $\begin{array}{c}\text { フェノール } \\
\text { 濃度 }(\mathrm{mg} / \mathrm{L})\end{array}$ \\
\hline Run1 & $1-48$ & 1.03 & $40-50$ \\
\hline Run2 & $49-85$ & 1.52 & 50 \\
\hline Run3 & $86-140$ & 4.08 & 50 \\
\hline Run4 & $141-158$ & 4.08 & 100 \\
\hline
\end{tabular}

表-6人工廃水中の有機成分, 無機成分濃度

\begin{tabular}{|c|c|c|}
\hline & 濃度 & 成分 \\
\hline \multirow{3}{*}{$\mathrm{DOC}$} & $40 \mathrm{mgC/L}$ & $\begin{array}{c}\mathrm{L}-\text { グルダン酸トリ片 } \\
\mathrm{C}_{5} \mathrm{H}_{8} \mathrm{NO}_{4} \mathrm{Na} \cdot \mathrm{H}_{2} \mathrm{O}\end{array}$ \\
\cline { 2 - 3 } & $40 \mathrm{mgC/L}$ & $\begin{array}{c}\text { メタノール } \\
\mathrm{CH}_{3} \mathrm{OH}\end{array}$ \\
\cline { 2 - 3 } & $20 \mathrm{mgC/L}$ & ポリペプトン \\
\hline $\mathrm{NH}_{4}-\mathrm{N}$ & $30 \mathrm{mgN} / \mathrm{L}$ & $\mathrm{NH}_{4} \mathrm{Cl}$ \\
\hline $\mathrm{PO}_{4}-\mathrm{P}$ & $4 \mathrm{mgP} / \mathrm{L}$ & $\mathrm{KH}_{2} \mathrm{PO}_{4}$ \\
\hline $\mathrm{Mg}^{2+}$ & $2 \mathrm{mgMg} / \mathrm{L}$ & $\mathrm{MgSO}_{4} \cdot 7 \mathrm{H}_{2} \mathrm{O}$ \\
\hline アルカリ度 & $214 \mathrm{mgCaCO} / \mathrm{L}$ & $\mathrm{NaHCO}_{3}$ \\
\hline $\mathrm{Ca}^{2+}$ & $14.915 \mathrm{mgCa} / \mathrm{L}$ & $\mathrm{CaCl}_{2}$ \\
\hline $\mathrm{Fe}^{3+}$ & $0.114 \mathrm{mgFe} / \mathrm{L}$ & $\mathrm{FeCl}_{3} \cdot 6 \mathrm{H}_{2} \mathrm{O}$ \\
\hline
\end{tabular}


加したケースとし, 残りのケースはオゾンの代わりに空 気を添加し，対照系として用いた。運転条件を表-4に示 す. 実験では流入オゾン濃度やフェノール濃度が異なる 4つの条件(Run 1 Run 4)を設定した. 各Runの条件を表-5 に示寸．また人工廃水は，有機物成分と無機成分に分け た溶液を作成し，有機成分を含有する溶液は冷蔵庫内で 貯留させ，無機成分のみを含有する溶液を別途貯留槽を 設け, 両溶液を最終的に表-6の濃度になるように流入 ・ 混合させた．各溶液は，水道水を用いて作製した．これ らの成分は都市下水や有機・無機成分や各々の濃度が都 市下水に近い産業廃水を想定した. 定期的に，生物反応 槽ならびにオゾン反応槽の水温，pH，DOを測定すると ともに，MLSS，SVIを測定した．処理水についても定期 的にサンプリングし，フェノール， DOC， $\mathrm{NH}_{4}-\mathrm{N}, \mathrm{NO}_{2}-$ $\mathrm{N}, \mathrm{NO}_{3}-\mathrm{N}, \mathrm{SN}, \mathrm{TN} の$ 濃度を測定した。. 以上の水質分析 は下水試験方法に淮拠した.

\section{3. 結果および考察}

\section{(1) オゾンによる污泥液化とフェノールの分解機構把握}

各実験ケース実施前後における水温は, ほぼ $16^{\circ} \mathrm{C} に$ 保 持されており，またpHは中性付近に維持されており，そ れらの変化による反応一の影響はほとんど無いものと考 えられた。污泥初期濃度が異なる各実験ケースでのフェ ノール濃度の経時変化を図-3に示す。污泥の初期濃度の 相違によるフェノール除去速度の差異はあまりなかった が污泥濃度の高いCase 3で初期の減少量が大きかった.

Case 4 においてもフェノール濃度低下が観察されたこと から，污泥一の吸着が影響しているものと考えられた。 陽イオン濃度の経時変化例としてK濃度の経時変化を図 -4に示す． 既往研究においても，オゾンによる污泥液化 の際にはK濃度が特に上昇することが報告されているす が，本研究においても同様の現象が観察された。特にフ エノールが添加されていないCase 5では1.6 mg/Lから3.6 $\mathrm{mg} / \mathrm{L}$ で増加し, 污泥がオゾンにより液化されているも のと考えられる.これらの結果から本実験で生ずる現象 について考察した. 図-5に反応槽内での反応経路の概念 図を示す，オゾンはフェノールと污泥に反応し，その速 度はそれぞれ $R_{1}\left[\mathrm{mgO}_{3} /(\mathrm{L} \cdot \mathrm{min})\right], R_{2}\left[\mathrm{mgO}_{3} /(\mathrm{L} \cdot \mathrm{min})\right]$ であると する. フェノールの酸化分解により分解生成物が生じる が，中性域でのオゾン酸化による無機化は生じにくいこ と ${ }^{10}$ やase 1の結果より無機化はほとんど生じていなかっ たため無機化については無視できるものとした．また污 泥の液化に伴い, $\mathrm{K}^{+}$や液化有機物が液中に放出されるが, 液化有機物は無機化まではなされないものとする．フェ ノールは污泥に $R_{3}\left[\mathrm{mg} 7\right.$ エル/(L·min)]で吸着( $\left(R_{3}\right.$ で脱着 $)$ さ れ，また曝気に伴い $R_{4}[\mathrm{mg} 7$ エルル/(L·min)]で系外に揮散す

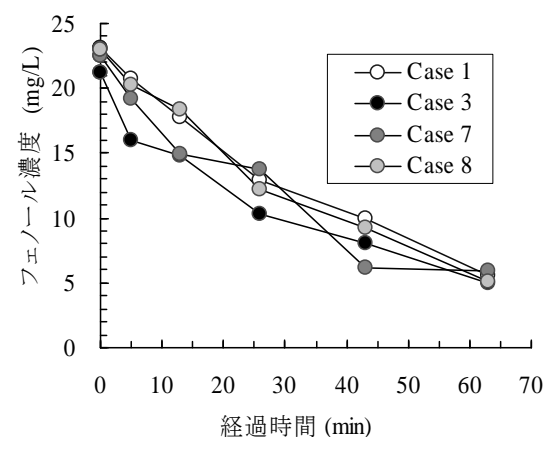

図-3 フェノール濃度の経時変化

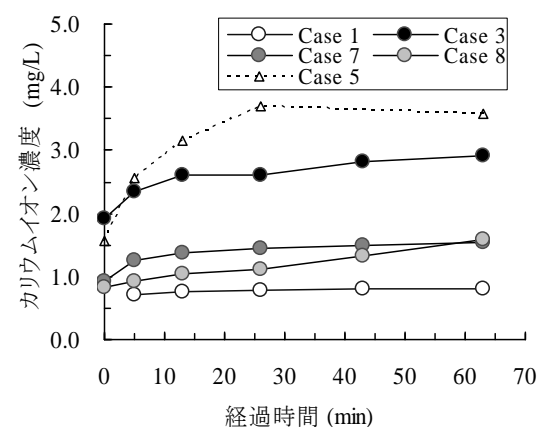

図-4 カリウムイオン濃度の経時変化

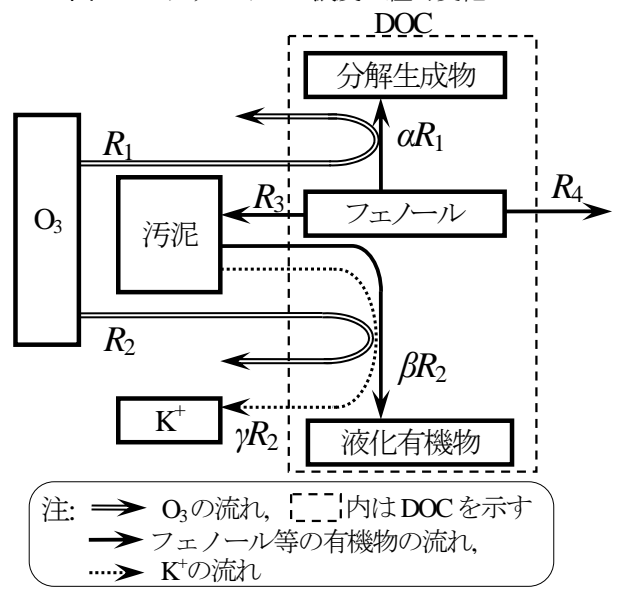

図-5 反応経路の概念図

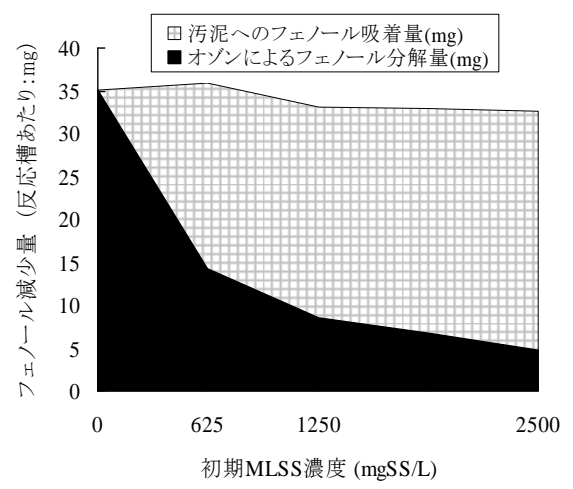

図-6 反応槽内でのフェノールの挙動 
るとする，このとき, フェノール, 溶解性有機物(DOC), カリウムイオンの物質収支式は各々下記(1)〜(3)のように なる.

フェノール $: V \frac{d(P h e)}{d t}=-V \alpha R_{1}-V R_{3}-V R_{4}$

有機物： $\quad V \frac{d(D O C)}{d t}=\left(-V R_{3}-V R_{4}\right) \omega+V \beta R_{2}$

カリウム : $\quad V \frac{d K^{+}}{d t}=V \gamma R_{2}$

ここで，V: 反応槽容積 [L]， $\alpha$ : オゾンによるフェノー ル酸化時での単位オゾン反応量あたりのフェノール反応 量 $\left[\mathrm{mg}_{\text {II }} / \mathrm{N} / \mathrm{mgO}_{3}\right], \beta:$ オゾンによる污泥酸化時での単位 オゾン反応量あたりの污泥液化量 $\left[\mathrm{mgC}^{\mathrm{mgO}} \mathrm{mg}_{3}\right], \gamma$ : オン゙ン による污泥酸化時での単位オゾン反応量あたりのカリウ ムイオン放出量 $\left[\mathrm{mgK}^{+} / \mathrm{mgO}_{3}\right], \omega:$ フェノールのDOC換算 比率 [mgC/mgフルル: 0.765]を表す. Case 2の結果よりフェ ノールの系外への揮散はないことが示され，本実験にお いてはR $R_{4}=0 \mathrm{mg}$ エノル/(L·min)であった. この結果と式(1) (3)より, オゾンのフェノールと污泥一の反応の割合を導 いた. まず $\alpha$ は d(Phe) $/ d O_{3}$ であり, Case 1の結果より求める ことが出来る． $\beta$ および $\gamma$ は各々 $d(D O C) d d_{3}$ ならびに $d\left(\mathrm{~K}^{\dagger}\right) d \mathrm{O}_{3}$ であり, Case 5の結果より算出することが出来る. Case 1および5の結果を基にオン゙ン，フェノール，DOCお よびK'の変化割合を, 時間変化から最小二乗近似して計 算した。 $\alpha, \beta, \gamma$ は各々 $0.523 \mathrm{mg}$ フルール $/ \mathrm{mgO}_{3}, 0.110$ $\mathrm{mgC} / \mathrm{mgO}_{3}, 0.164 \mathrm{mgK}^{+} / \mathrm{mgO}_{3}$ と算出された. これらはモル

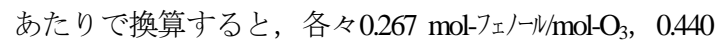
mol-C/mol- $\mathrm{O}_{3}, \quad 0.201 \mathrm{~mol}-\mathrm{K}^{+} / \mathrm{mol}^{-\mathrm{O}_{3}}$ である. 従来の知見では, オゾンによる污泥酸化時での単位オゾン反応量あたりの 污泥液化量として0.42-2.04 mgC/mgO 3 が報告されており ${ }^{177}$, それとの比較では, 本研究での $\beta$ 值は低かった. $\beta$ 值は污 泥性状により変化する可能性は考えられ, 直接的な要因 は不明であるが，フェノールと活性污泥共存下において， オゾンは双方を同時に酸化させることが示された，以上 の計算值に基づき，本実験ケースでの反応槽内の挙動に ついて定量的に解析した. オゾンによるフェノール分解 量はそれぞれCase 1で35.1 mg, Case 3で4.68 mg, Case 7で $8.61 \mathrm{mg}$, Case 8で14.30 mg となった. オゾン添加により污 泥の可溶化(液化)とフェノールの酸化分解は同時に発現 することがわかった，今回の実験条件では，污泥の存在 量が増加するにつれて, フェノールの污泥一の吸着量は 増加しそれに伴いオゾンによる分解量は漸減したが，フ ェノールの減少量は污泥の存在量に関わらず同程度の結 果となった. それらの関係を図-6に示す。

次にEDCsの処理結果について示す. 例としてE2の残 存率とオゾン消費量との関係を図-7に示す.Case 9にお
いて, 水相中E2の残存率が高くなっている. その他の Case 10およびCase 12においてはオゾン消費量 $20 \mathrm{mgO}_{3} / \mathrm{gSS}$ 程度で, Case 11においてはオゾン消費量 $50 \mathrm{mgO}_{3} / \mathrm{gSS}$ 程度 で減少が止まっている，污泥相中E2は，どのCaseにおい ても同様にオン゙ン消費量約 $30 \mathrm{mgO}_{3} / \mathrm{gSS}$ までに急激に減少 しており, 残存率は0.1 0.4程度であった. 污泥が混在し ていてもEDCsはよく除去されることが示された.ここ で，エストロゲン性物質の分解速度について考察する. オゾンとエストロゲン性物質の反応およびオゾンとSSの 可溶化反応が二次反応であるとする (5)により分解速度および可溶化速度が表される.

$$
\begin{aligned}
& R_{E D C S}=-\frac{d[E D C s]_{T}}{d t}=k_{\mathrm{EDCS}} \cdot[E D C s]_{\mathrm{T}} \cdot\left[\mathrm{O}_{3}\right] \\
& R_{\mathrm{SS}}=-\frac{d[S S]}{d t}=k_{\mathrm{SS}} \cdot[\mathrm{SS}] \cdot\left[\mathrm{O}_{3}\right]
\end{aligned}
$$

ここで, $\mathrm{t}$ : オゾン処理時間 (s), $[E D C S]_{\mathrm{T}}$ : エストロゲ ン性物質濃度(水相中+污泥相中) $(\mathrm{M}),\left[O_{3}\right]$ : オゾン濃度 (M), [SS] : SS濃度 (mgSS/L), $k_{\mathrm{EDCS}}$ : 分解速度定数 $(1 /(\mathrm{M} \cdot$ $\mathrm{s})), k_{\mathrm{ss}}$ : 可溶化速度定数 $(1 /(\mathrm{M} \cdot \mathrm{s}))$

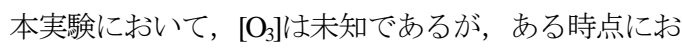
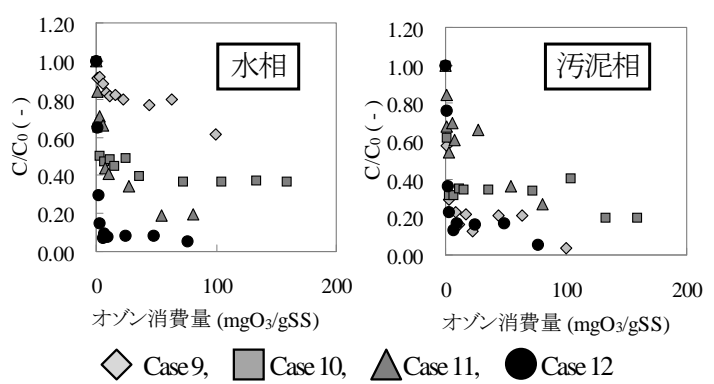

$\diamond$ Case9, $\square$ Case 10, $\triangle$ Case 11, Case 12

図-7 E2 の残存率とオゾン消費量との関係

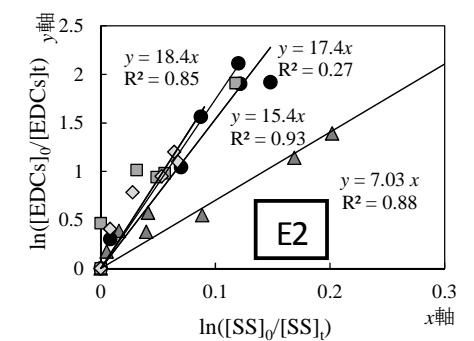

$\diamond$ Case9, $\square$ Case 10, $\triangle$ Case11, $\bigcirc$ Case 12

図-8 $k_{E D D C} k_{S S}$ 值の決定

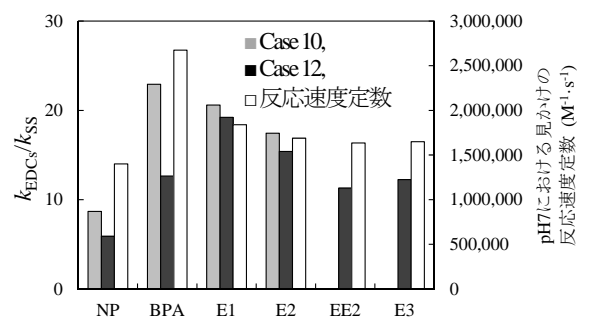

図-9 EDCs $の k_{\mathrm{EDC}} k_{\mathrm{sS}}$ 值と反応速度定数 
ける反応器内 $\left[\mathrm{O}_{3}\right]$ は一定であるため, エストロゲン性物 質の除去速度はSSの可溶化速度との比において算出しう る. 式(4)および式(5)より, 式(6)が導かれる.

$$
\ln \left(\frac{[E D C s]_{\mathrm{T}, 0}}{[E D C s]_{\mathrm{T}, t}}\right)=\frac{k_{\mathrm{EDCs}}}{k_{\mathrm{SS}}} \cdot \ln \left(\frac{[S S]_{0}}{[S S]_{t}}\right)
$$

ここで, $\mathrm{t}$ : オゾン処理時間 [s]

各Runにおける各エストロゲン性物質について，図-8 に示すように，横軸に $\ln \left([\mathrm{SS}]_{0}[\mathrm{SS}]_{t}\right)$ を，縦軸に

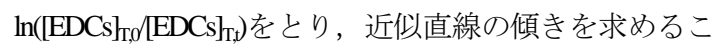
とにより， $k_{\mathrm{EDC}} / k_{\mathrm{SS}}$ 值を計算できる．ここで， $k_{\mathrm{EDCS}} k_{\mathrm{SS}}$ の值 が大きい場合, SS の可溶化と比較してエストロゲン性物 質は分解されやすいことを意味する．図には例としてE2 の反応特性を示した. エストロゲン性物質を添加して実 験を行ったCase 10およびCase 12より求められた各エスト ロゲン性物質の $k_{\mathrm{EDC}} \mathrm{s} k_{\mathrm{SS}}$ 值を図-8により求め, 污泥が存在 しない場合のオゾンと各エストロゲン性物質とpH6.7(本 実験における初期 $\mathrm{pH}$ におおける見かけの反応速度定数 ${ }^{18)}$ と あわせて図-9に示寸．EE2およびE3については，Case 10 においてはオゾン処理時間10分以上で検出されなかった ため, Case 12の值のみ示した. 污泥が存在しない場合, BPAの反応速度定数は他よりやや大きく, NPの反応速度 定数はやや小さい，E1，E2，EE2，E3はこの順に少しず つ小さい值となっている. Case 10およびCase 12における $k_{\mathrm{EDC} S} k_{\mathrm{SS}}$ 值を比較すると, Case 12のBPAを除いて, 污泥が 存在しない場合と類似した傾向にあることが分かった. また， $k_{\mathrm{EDC}} / \mathrm{k}_{\mathrm{SS}}$ 值は，高SS濃度であったCase 12の方が低SS 濃度のCase 10 と比較してやや小さくなることも示されて いる. 各EDCsの挙動観察から, 標準法での污泥と AO 法での污泥間で特徽的な相違は見られなかった.いずれ にせよ，污泥が共存していたとしても，污泥が存在しな い場合の反応速度定数によって，ある程度はオゾンとの 反応しやすさが表せることが示唆された。同様の現象は フェノールの場合においても観察された。

\section{(2) オゾン添加活性污泥法による連続処理特性}

SVI, フェノール濃度, アンモニア性窒素濃度, 硝酸 性窒素濃度の経日変化を図-10にまとめて示す，SVIは Run 1からRun 2において両系列とも污泥投入直後は良好 な状態が維持されていたが，処理の経過に伴い悪化する 傾向にあった. オゾン系列では沈降性改善傾向が観察さ れたものの空気系列と同様にバルキング状態になった. フェノール含有廃水処理時は系状菌が優先となりやすい 状況であり, バルキングが発生する状況であった. オゾ ン濃度を1.52 $\mathrm{mgO}_{3} / \mathrm{L}$ から $4.08 \mathrm{mgO}_{3} / \mathrm{L}$ に上げたRun 3ではオ ゾン系列は一時的な上昇はあるが110 633 mL/g となり良 好な状態を保った。一方空気系列では沈降性は改善され なかった.フェノール濃度を50 mg ェノル/Lから100 mgフル
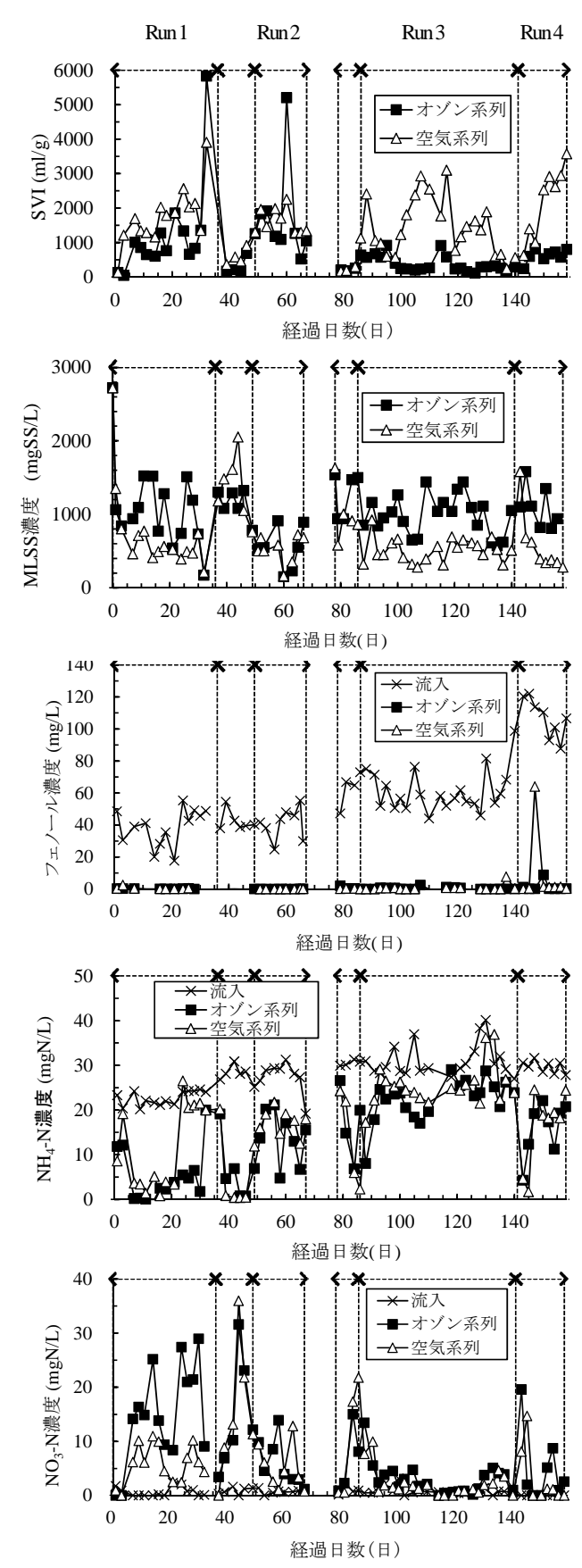

図-10 SVI，MLSS 濃度，フェノール濃度，アンモニア 性窒素濃度, 硝酸性空素濃度の経日変化

ル/に変更したRun 4では，オゾン系列のSVIは240 819 $\mathrm{mL} / \mathrm{g}$ なった. また空気系列でのSVIは626 mL/gから3570 $\mathrm{mL} / \mathrm{g}$ に上昇した. 両系列ともバルキング状態であるが, オゾンを添加しているケースの方がその度合いは小さく なっている．なお，SVIが高いときには，固液分離を確 実とし, 系内に微生物を保持するために, 流出水を貯留 
し膜ろ過や遠心分離操作を加え, 污泥を系内に返送し, SRTを5日以上確保するようにした。

処理水中のフェノールはRun 1からRun 3を通じて良好 に処理された. フェノール濃度を $100 \mathrm{mg}$ エルールんに変更 したRun 4開始時では, 流入水のフェノールの急激な変 化で空気系列の処理水中のフェノール濃度は一時的に $63.9 \mathrm{mg}$ エェール/Lまで上昇したがオゾン系列はそこまでの 濃度上昇は見られず啇切に処理された。フェノールは 硝化活性を阻害する物質であることから, 硝化は抑制 されることが予測されたが, 実際Run 1においては空気 系列は部分的な硝化は進行するものの完全硝化には至 らなかった(アンモニア性窒素平均濃度 $11.4 \mathrm{mgN} / \mathrm{L}$, 硝酸 平均濃度 $5.8 \mathrm{mgN} / \mathrm{L})$. 一方オゾン系列での硝化の発現が 著しく, 空気系列との差が明らかとなった(アンモニア 性窒素平均濃度 $5.1 \mathrm{mgN} / \mathrm{L}$ 、硝酸性窒素平均濃度 15.0 $\mathrm{mgN} / \mathrm{L})$. フェノール負荷が小さいときには, オゾンに よりフェノールが除去され, 結果として硝化が安定し て発現する結果となった。 しかし, フェノール濃度を 上げたケースでは, 沈降性改善はなされるものの, 硝 化発現を十分に維持するまでには至らなかった.

ここで, オゾン消費率(単位污泥量あたりのオゾン消 費量)と污泥沈降性との関係を図-11に示寸. 連続処理時 におけるオゾン消費率は以下の式(7に従い算出した.

オゾン消費率 $\left[\mathrm{mgO}_{3} / \mathrm{gSS}\right]=\frac{\left(C_{\text {in }}-C_{\text {out }}\right) Q_{g}}{X_{r} Q_{r}}$

ここで， $C_{i n}$ オゾン反応槽に注入するオゾンガス濃度 $\left[\mathrm{mgO}_{3} / \mathrm{L}\right], C_{\text {aut: }}$ オゾン反応槽からの排出オゾンガス濃度 $\left[\mathrm{mgO}_{3} / \mathrm{L}\right], Q_{\mathrm{g}}$ : オゾン化空気注入流量 $[\mathrm{L} / \mathrm{min}], X_{\mathrm{r}}$ : 返送污泥 濃度[gSS/L]， Q: 污泥返送流量[L/min]

オゾン添加系においてもバルキング状態を示寸期間が 長かったが，空気系との相違を示すため，SVI值の比を 示した. 流入オゾン濃度が高い条件で, 沈降性が改善さ れていることが分かる. オゾン消費率が50 mgO/gSS以上 では, SVI值の比が 0.2 程度以下となり，オゾン添加の効 果により沈降性が5倍以上改善されることが分かる。ま たいずれの時点でもこの比が1を超えることはほとんど なく, オゾン添加が沈降性改善に寄与していることが示 されている. オゾン添加による污泥の濃縮性の改善や沈 降性の改善、バルキングの抑制はオゾン消費率が 60 $\mathrm{mgO}_{3} / \mathrm{gSS}$ までの範囲で生じることが，従来の研究におい ても報告されている ${ }^{9199,20)}$. 本研究でも同程度のオゾン 消費率で同様の効果が生じることが示されている．また オゾン消費率と硝化率の関係を図-12に示す．フェノー ル負荷が低くオゾン消費率も小さいRun 1では硝化率が 高く, オゾン消費率が $15 \mathrm{mgO}_{3} / \mathrm{gSS}$ 程度までは硝化率は

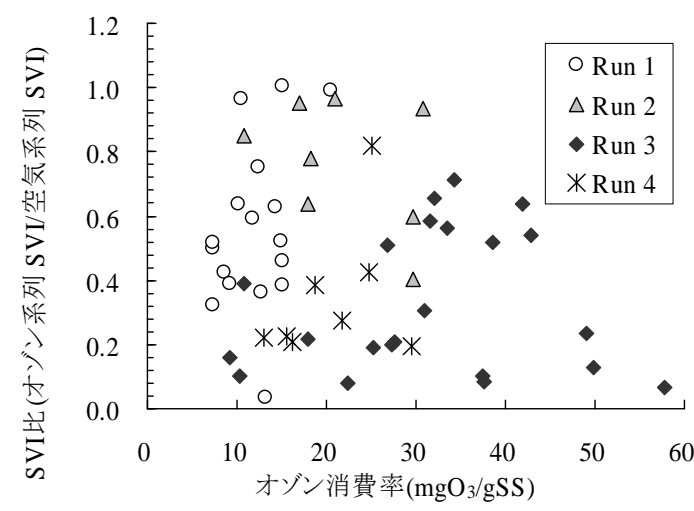

図-11 オゾン消費率と污泥沈降性の関係

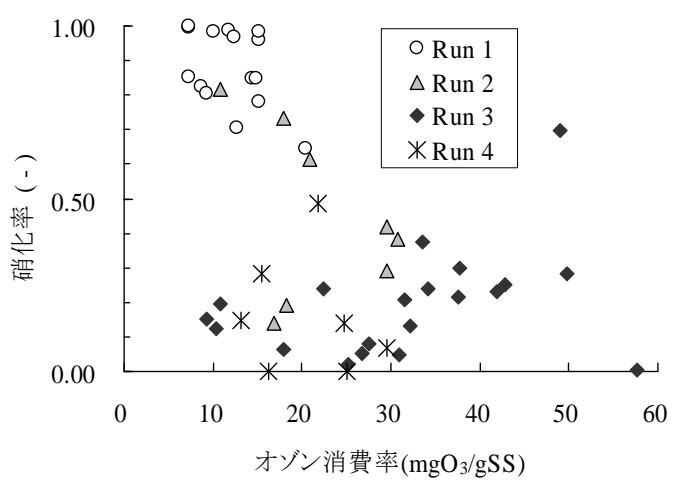

図-12 オゾン消費率と硝化率の関係

70\%以上になり，それ以上になると硝化率低下が観察さ れる. オゾン添加量を増大させるとオゾンの酸化力によ り活性が低下寸るが，フェノール負荷が高いRun 3,4では むしろオゾン消費率が高い条件で硝化率が高くなってい る. オゾンによりフェノールが分解され，その生物活性 阻害性が除去されるため, この条件ではオゾンを添加す る方が污泥の硝化能を高く維持できる結果となった.

\section{4. まとめ}

1) オゾン添加により污泥の可溶化(液化)とフェノールの 酸化分解は同時に発現することがわかった。 廃水の性状 に応じてオゾン添加量を制御することで，污泥の可溶化 と生物活性阻害性物質の除去をなし得, 安定した処理が 行えるものと考えられる.

2) オゾン消費率が $15 \mathrm{mgO}_{3} / \mathrm{gSS}$ ま゙の範囲では，污泥の硝 化活性は阻害されなかった．高フェノール負荷時では硝 化活性は低下寸るが， 50 mgO/gSSまでのオゾン添加では 無添加系と比較して硝化活性は高く維持される結果とな った.

3) 污泥が存在しない場合に求められるEDCsのオゾンと 
の反応速度定数は，污泥存在下におけるEDCsの反応の しやすさに対応していることがわかった. 微量有機污染 物質の污泥存在下での反応特性は, 既知の反応速度定数 を用いて予測しうることが示唆された。

4) オゾン消費率が28〜 $40 \mathrm{mgO}_{3} / \mathrm{gSS}$ の時にはSVIは改善さ れた. オゾン消費率が50 mgO/gSS以上では, オゾン添加 の効果により沈降性が改善され, SVIも $110 \mathrm{~mL} / \mathrm{g}$ まで改善 される結果となった.

オゾン添加活性污泥法は, 沈降性改善や硝化活性の維 持の面から, 従来法よりも優れていることが分かった. 発生污泥量削減の観点から開発されたオゾン添加活性污 泥法であるが，処理の安定性向上の観点からも利点があ ることが実験を通じて明らかになった.

謝辞 : 本研究の一部は, 科学研究費(若手研究B 課題番号 16760444)ならびに平成17年度愛媛大学研究開発支援経費 (萌芽的研究)，平成22，23年度鉄鋼環境基金(一般研究助 成)の補助を得て実施されました。また本研究を遂行す るにあたり, 愛媛大学大学院理工学研究科水環境工学研 究室のスタッフならびに学生諸氏からは多大な協力を得 ました.ここに記して謝意を表します。

\section{引用・参考文献}

1) N.I. Galil, A. Schwartz-Mittelman, O. Saroussi-Zohar: Biomass deflocculation and process disturbances exerted by phenol induced transient load conditions, Wat. Sci. \& Tech., Vol.38, Issues 8-9, pp.105-112, 1998.

2) 高部祐剛, 津野洋, 西村文武, 坂本昌則, 寺杣優一: 下水の生物 学的処理における天然エストロゲンの除去機構に関する研 究,環境工学研究論文集,第 47 巻,pp.707-717, 2010.

3)宗宮功:オゾン利用水処理技術, 公害対策技術同友会, p.58, 1989.

4) Zhang, Z., Zhu, H., Wen, X., Si, X.: Degradation behavior of 170ethinylestradiol by ozonation in the synthetic secondary effluent, $J$. of Environ. Sci., Vol. 24, No. 2, pp. 228-233, 2012.

5) Esplugas, S., Bila, D. M., Krause, L. G T., Dezott, M.: Ozonation and advanced oxidation technologies to remove endocine disupting chemicals (EDCs) and pharmaceuticals and personal care products (PPCPs) in water effluents, J. of Hazardous Materials, Vol. 149 No. 3, pp.631-642, 2007.

6) 荒川清美, 葛甬生, 小林玩也, 田中俊博: オゾンを用いた活性污泥 法における污泥減容化の基礎的研究, 環境工学研究論文集, Vol. 37,pp.107-118, 2000.

7) H. Yasui, and M. Shibata: An innovative approach to reduce excess sludge production in the activated sludge process, Wat. Sci. \& Tech., Vol.30, No.9, pp.11-20, 1994.

8) T. Kamiya and J. Hirotsuji: New combined system of biological process and intermittent ozonation for advanced wastewater treatment, Wat. Sci. Tech., Vol.38, No.8-9, pp.145-153, 1998.

9) 金暎蘭, 宗宮功: オゾン処理による活性污泥の系状バルキング制 御効果の定量化, 環境技術, Vol.27, No. 8,pp.590-597, 1998.

10) Lyko S., Teichgräber B., Kraft A.: Bulking control by low-dose ozonation of returned activated sludge in a full-scale wastewater treatment plant, Wat. Sci. \& Tech., Vol. 65, No.9,pp.1654-1659, 2012.

11)横路朋子, 宗宮功, 藤井滋穂, 藤原拓: オゾン処理による下水の凝 集特性に関する研究, 第 8 回 日本オゾン協会年次研究講演会 講演集,pp.142-145, 1999.

12)社団法人下水道協会編: 下水試験方法-1997年版-

13) 社団法人下水道協会編: 下水試験方法(追補暫定版) -内分泌攪 乱化学物質編及びクリプトスポリジウム編-, 2002.

14) Waters: Estrogens in river water at $5 \mathrm{ng} / \mathrm{L}$ (Endocine Disnupters), (http://www. waters.com/webassets/cms/ibrary/docs/oasis80.pdf)

15) 坂本昌則: 嫌気好気条件下での活性污泥によるエストロゲン 性物質の除去挙動,2007 年度京都大学大学院修士論文,2008.

16) Fumitake NISHIMURA, Go KATOH, Taku FUJIWARA: Improvement and Reduction of Activated Sludge by ozonation and its application to wastewater treatment, Proc. of the 15th OZONE WORLD CONGRESS, London 2001, Vol. 1, pp.324-331, 2001.

17) 特定非営利活動法人 日本オゾン協会 オゾンハンドブック編 集委員会: オゾンハンドブック,サンユー書房, 403p, 2004.

18) M. Deborde, S. Rabouan, J.P. Duguet, B. Legube; Kinetics of Aqueous Ozone- Induced Oxidation of Some Endocrine Disuptors, Environ. Sci. \& Tech., Vol. 39, pp.6086-6092, 2005.

19) 荒川清美, 田中俊博: りん除去工程を組み込んだオゾンによる 污泥減容化の検討, 環境衛生工学研究, Vol.17(4), pp.62-69, 2003.

20) 日本オゾン協会: 水利用の合理化・再利用のためのオゾン処 理要素技術(オゾン発生器, オゾン反応槽, オゾン処理シス テムの現状と動向), Vo1.503,pp.50-60, 2000.

(2012.5. 25 受付) 


\title{
Treatment Characteristics of Wastewater Containing Organic Trace Contaminants in Ozone-Added Activated Sludge Process
}

\author{
Fumitake NISHIMURA ${ }^{1}$, Yukiko OKADA ${ }^{2}$, Michiko MASUDA ${ }^{3}$, \\ Yuko NAKAGAWA ${ }^{1}$, Taira HIDAKA ${ }^{4}$, Taku FUJIWARA ${ }^{5}$ and Hirosh TSUNO ${ }^{1,6}$
}

\author{
${ }^{1}$ Dept. of Environmental Engineering, Kyoto University \\ ${ }^{2}$ Yonden Consultants Incorporated \\ ${ }^{3}$ Dept. of Architecture and Civil Engineering, Nagoya Institute of Technology \\ ${ }^{4}$ Public Works Research Institute \\ ${ }^{5}$ Agriculture Unit, Natural Sciences Cluster, Research and Education Faculty, Kochi University \\ ${ }^{6}$ Osaka Sangyo University
}

Ozone-added activated sludge process is one of the modified processes for reduction of excess sludge production. Although ozone-added activated sludge system was originally developed in order to reduce excess sludge production, it is expected that its direct ozonation to activated sludge can also remove some biorefractory compounds by chemical oxidation, and the treatment efficiency and stability can be increased as results. In this study, phenol was used as a biorefractory compound in wastewaters and behaviors of EDCs at sludge ozonation were also investigated in order to evaluate several functions of ozone-added activated sludge process. The treatment characteristics were investigated with lab scale experimental setups. It is made clear that direct ozonation to activated sludge within a range of 15 $\mathrm{mgO}_{3} / \mathrm{gSS}$ does not inhibit biological activities and biorefractory compound(phenol) is promptly removed chemically. On the other hand, the experimental case without ozonation can not remove phenol quickly and biological activity is inhibited by existence of phenol. These results suggest that the system can treat wastewaters which contain biorefractory compounds effectively and stably besides both bulking control and low excess sludge production. 